\title{
SPECTATORS' UNDERSTANDING OF THE ENVIRONMENTAL IMPACTS OF A SPORT EVENT IN PORT ELIZABETH, SOUTH AFRICA
}

\author{
Hugh BARTIS* \\ Nelson Mandela University, Tourism Department, Port Elizabeth, South Africa, e-mail: Hugh.bartis@mandela.ac.za
}

Sibusiso TOFILE

Nelson Mandela University, Tourism Department, Port Elizabeth, South Africa, e-mail: sstofile@gmail.com

\begin{abstract}
Citation: Bartis, H., \& Tofile, S. (2021). SPECTATORS' UNDERSTANDING OF THE ENVIRONMENTAL IMPACTS OF A SPORT EVENT IN PORT ELIZABETH, SOUTH AFRICA. GeoJournal of Tourism and Geosites, 35(2), $282-288$. https://doi.org/10.30892/gtg.35203-649
\end{abstract}

\begin{abstract}
The main aim of this study was to investigate the spectators understanding of the environmental impact when a sport event is hosted. The study focused on the Town Lodge Business Relay (TLBR) event, an annual event hosted in Port Elizabeth, South Africa. This event entails companies (corporates) entering relay teams, which compete again other teams. A quanti tative approach was followed, using non-probability sampling and with spectators completing a self-administered questionnaire. The outcome of the study revealed pertinent demographic details about the spectators and indicated that most of the spectators (respondents) generally understood the environmental impact of sport events.
\end{abstract}

Key words: environmental impacts, spectators, sustainability, sport events destinations

\section{INTRODUCTION}

The main purpose of this paper is to investigate the spectators' understanding of the environmental impact of sport events in Port Elizabeth (PE), specifically those spectators who attended the Town Lodge Business Night Relay (TLBNR) event. The environment is one of the important tourism resources that needs to be conserved and protected constantly, so as to ensure that future generations can derive the same benefit. Therefore, sporting activities need to be designed in a sustainable manner, so that events do not lead to the degradation of the environment.

At the same time, sporting events can be used to enhance the image of a destination, as well as to improve the attractiveness of the said destination (Higham, 2005; Hemmonsbey and Tichaawa, 2019). In support of the above statement, an improvement in a destination's attractiveness means that a large number of people may visit a destination, which which may result in either postive or negative environmental impacts. The spectors and participants of an event can contribute to several outcomes, such as the preservation of the physical landscape and local heritage, the provision funds for conservation efforts and may even have an impact on climate change, environmental destruction, waste and the over-consumption of natural resources (Barber, 2014). For this reason, it is necessary to plan events so that the negative impacts are mitigated, as best as possible. The significance of this study is that it provides valuable insight into how spectators think about the environment, and how aware of the environment the spectators are to sport events.

This suggest that sport event planners, sport administrators, hosts of sport events, and prospective sponsors of sport events, need to consider the environment where the sport event is held, as resource. Therefore, stakeholders of sport events need to pro-actively plan to ameliorate any possible environmental risks and not only focus on financial and health benefits of an event and participants, respectively. In doing so, they need consider making the destination where the sport event is hosted, more sustainable and appealing to spectators, participants and the host community.

\section{Study Area}

The TLBNR is an event that is held annually in the Port Elizabeth, South Africa, using the Nelson Mandela Bay Stadium (NMBS) precinct. The event is held on a course around the stadium, adjoining the neighbourhood over a period of four evenings. This enables the immediate community and others who travel to the event to support their family and loved ones, who participate in the event. The TLBNR is a team-based event for running and walking, where each participant in each of the teams are required to run or walk a 3.5 kilometre lap of the course. This event normally takes place over four days between May and August, as part of relay race. The field work was conducted on each of the four days, when the relay event took place.

\section{LTERATURE REVIEW}

Profiling of Spectators at Sport Events

The profiling of spectators (fans) is key in understanding who they are and what the specific needs are. For this reason, it is 
necessary to segment spectators based on a number of variables such as age, gender, education, income, ethicity, amonst other and to design events and resources that would cater for these different segments (Florek et al., 2008; Smith and Stewart 2007; Stander and Van Zyl, 2016; and Kaiser et al., 2019). Jones (2008) also stated that the spectators at sport events consist of a mix of local community and casual spectators, whose sole objective is not necessarily the sporting event itself, but also to enjoy themselves at the host destination. In addition, a study by Achu et al., (2015) revealed that the sport event spectators are generally young (18 to 34 years old) and well educated, with the majority having obtained a diploma or a postgraduate degree.

Due to the differing reasons why male and female spectators travel to a sport event, it has become necessary to profile the spectators, in order to pick up on such differences or similarities where necessary, and to modify event packages accordingly (Smith and Stewart, 2007; Nyikana, 2013). The other reason for this is that managers and marketers need to focus their efforts to optimise their limited resources (Ramukumba, 2016). Therefore, a need exists to segment your spectators, so that your have a better understanding of their origin, their needs and preferences (Stander and Van Zyl, 2016; Kaiser et al., 2019). Furthermore, it is suggested that through market segmentation, a spectator profile can be developed that will enable event organisers to concentrate resources and efforts so that an optimal return on investment can be obtained (Doole and Lowe, 2001).

\section{The Environment as a Resource}

For any host region, or destination it is key to ensure that the natural environment is considered as a key resource. Equally important is to ensure that the environment is not degraded as it is a natural resource that contributes to the competitiveness of a destination. This implies that greater attention ought to be accorded to the environment, as the natural environment is one of the resources that not only attracts visitors (athletes and spectators), but also provides the basis in which the activity is practised. It is asserted that the importance of the natural environment demands a greater investigation into the sustainable usage thereof, by both the tourism and the sport sector (Kruger, 2015), as their activities often impact on the environment. Therefore, greater emphasis should be placed so as to ensure that both participation in a sport and recreation activities are conducted in an environmentally sustainable manner.

According to Kruger (2015) natural resources, such as beaches, are key components in tourism development and has the potential to steer sustainable development, by improving resource efficiency. The natural en vironmental resources serve as a catalyst at a destination, and has the capacity to promote growth. On the other hand, events ought to be supported by municipalities as it has the propensity to boost the local economy (McKay et al., 2019) and by implication, the tourism destination The growth in tourism destinations, in turn, may lead to an increase in pressure being exerted on the environment (Du Plessis, 2010). The author suggests that to counter this pressure, a 'greener' form of tourism should be nurtured, to reduce environnmental impacts, by applying sustainable management approaches (Du Plessis, 2010), in activities which are prractised in the environment. Therefore, the need for sporting events to be environmentally friendly is key, so as to reduce the overall impact on the environment. For this reason, it may be necessary to investigate whether spectators understand the importance of the environmental impacts brought about by sports events.

\section{The Relationship between Environment and Sport Events}

Sport events are viewed as one of the key activities that are used as a vehicle for the growth and develiopment of many countries. Many factors contribute to the rapid growth and development of a country, or region, sports events are one of the preferred activities (Fourie and Santana-Gallego, 2011 cited in Nyikana, 2013). Higham (2005) believes that sport can be used as tool to enhance the image of a destination, as well as to improve the attractiveness of the destination.

The flipside of this is that the impact of sport may impact on the environment. Therefore, these impacts require appropriate management from the planners and the event organisers. According to Ritchie and Crouch (2003) a destination's competitiveness is related to the destination's ability to increase expenditure, while simultaneously facilitating the well-being of destination residents and preserving the natural environment, for future generations. With this definition the sustainable and effective use of an environment is emphasised and it should also be incorporated in sport events. Kruger (2015) states that the availability of resources or the lack thereof may allow or prevent a destination from offering certain products and experiences to visitors (athletes and spectators). Therefore, the lack of resources may lead to an absence of quality environmental space, which may, in turn, inhibit a destination from being attractive and competitive.

\section{Environmental Impact of Sport Events}

Globally, events have been recognised as an approach to attract visitors to a destination. It is also widely known that events may have specific impacts on the host destinations. These impacts are likely to recognised when examining at the environmental, social and economic significance of the host destination, where the events are held (Bjelac and Radovanovic, 2003). For the purpose of this paper, the environmental impacts of sport events are the focus of the study. The terrestrial environmental impacts are influences that affect the carrying capacity of the a particular area, the vegetation, its air and water quality, wildlife, and natural phenomena. According to Kiani and Nazari (2019) sporting events leads to increased consumption, energy, the emission of greenhouse gases and also generate waste, which necessitates the need for sustainable management. The discussion below presents both positive and negative environmental impacts of sport $t$ events on host communities. Sports events have the capacity to serve as a catalyst for attracting attention to the natural environment, which helps in preserving some elements of the physical environment and of the local heritage that would otherwise be ignored. Sport events may contribute to urban gentrification (renewal), an improved economy, as well as the ability to enhance the quality of 
life of locals (Hemmonsbey and Tichaawa, 2019; Achu, 2019). Therefore, sports events have the ability to promote environmental protection in host communities through specific strategies that will decrease carbon emissions, or to minimise water usage, by creating environmental awareness amongst the local population and visitors by adopting specific mitigation initiatives to address environmental concerns. These initiatives are likely to minimise the negative environmental impacts from sport events and reduce the impact on the environment. As a consequence, the environment may be more appealing.

Sport events held in local areas could attract the interests of sponsors to contribute to conserving the host environment. These contributions would maintain the appeal of destinations that depend on the natural environment, which may then result in a higher demand for to visit such destinations (Goeldner and Ritchie, 2012). Therefore, sport organizers and event managers have a responsiblility towards the natural environment by ensuring that the environment is treated in a sustaianble manner.

Hosting sport events in local areas can also contribute to the development of local infrastructure. One of the positive environmental impacts of improved infrastructure relates to new physical development, such as stadia, transport infrastructure, airport capacity and upgrades in water and sewage services, which may not been politically or financially feasible without the event (Dodouras and James 2004; Achu, 2019). Sport events can also serve as a catalyst to creates environmental awareness through the promotion of greening concepts during the event (Achu, 2019). This could contribute to the spectators being environmentally aware and hopefully more environmentally responsible. This would ensure that issues such as excessive water usage and littering during sport events are minimised. Negative impacts on the environment are categorized according to resource usage, namely human behaviour towards the destination environment (Holden, 2009 cited in Kruger, 2015). According to Kepulić et al., (2020) sport events present particular challenges such as waste pollution, air pollution, water pollution and abnormal noise levels. Pollution may be the result of spectators littering and not bagging, or containing their waste, or noise pollution. For example, if spectators use loudhailers, or vuvuzela to cheer on their athletes. Therefore sport event organisers may need to create a greater awareness amongst spectators to be environmentally responsible.

Other negative impacts of sport events may include waste and over-consumption of natural resources during events (Kiani et al., 2019 and Kepulić et al., 2020). Additionally, as some of these events occur in an environment, they may eliminate the amount of open spaces, which then detracts from the appeal of an environment, resulting in an unattractive destination for locals and visitors. In the case of waste and over-consumption of natural resources, this may include excessive water use during the hosting of the event which can result in water shortages at that destination. Sport events can also lead to overcrowding at a host destination. Overcrowding refers to a situation where more people are concentrated in a certain area than is considered acceptable from a safety and health perspective. Overcrowding, or congestion in a host destination can also lead to the damage to the local environment. Overcrowding is often blamed on poor planning, as event managers fail to take into account the environmental impact issues before the event is hosted. Although overcrowding at the host destination is primarily a temporary problem, its impact may be long lasting. During the COVID-19 pandemic, overcrowding is even more critical, since not following the prescribed safety protocols may contribute to the spreading of the virus.

\section{MATERIAL AND METHODS}

The research design adopted for this study is descriptive in nature. The descriptive reseach design involves either identifying the characteristics of an observed phenomenon, or exploring possible associations amongst two or more phenomena (Leedy and Ormond, 2015). These authors further explained that descriptive research examines a situation as it is. The reason for using the descriptive research design in this study is because the questions that would dominate in the data collection instrument were closed questions, such as, a five-point Likert-type scale and rating questions.

The data collection method involved the use of self-administered questionnaire using field workers during each of the four evenings that the event took place. The questionnaire was aimed at the respondents' understanding of the environmental impacts of the 2018 Town Lodge Business Night Relay (TLBNR) event. The targeted population for this study were the spectators at the TLBNR event. The targeted population refers to the whole group of individuals or objects in which the researcher is interested and from which he generalises conclusions about the study (Mboyiya, 2017). The targeted population included adults over 18 years old; both males and females. In this case, it was also a filter question, as respondents younger than 18 years of age were excluded from the study. Once respondents confirmed that they were older than 18 years of age, their consent were obtained, allowing them to participate voluntarily in the survey. Since, the spectators did not constitute any vulnerable groups, it was not necessary to obtain ethics clearance for the study from the university at the time that the fieldwork was conducted. The sample included 119 respondents $(n=119)$.

The respondents answered a self-administered questionnaire that was distributed by four (4) fieldworkers at the NMBS precinct, during the time that the event was held on each of the evenings. The self-administered questionnaires contained mostly closed questions. These closed questions included multiple choice, Likert scale type questions, and rating questions. The reason for using these closed questions was because the current study had adopted a quantitative approach.

The value of adopting a quantitative approach is data can be changed into useable statistics and can be used to quantify attitudes and behaviours. Non-probability convenience sampling was used for the study, even though this method poses some limitations, such as the representivity of the sample (Leedy and Ormrod, 2015). Convenience sampling is a nonprobability sampling technique where subjects are selected because of their convenient accessibility and proximity to the researcher (Leedy and Ormrod, 2015; Altinay et al., 2016). It enabled the reseacher to collect data during a defined period of time, when the spectators were accessible during the event. The data was captured on Excel, where-after Excel was also used to conduct statistical analyses with a $95 \%$ confidence level and a 5\% margin of error. 


\section{RESULTS AND DISCUSSION}

\section{Demographics of Respondents}

The majority (71\%) of the spectators of the TLBNR resided in Port Elizabeth, with $29 \%$ of these respondents (spectators) residing outside of Port Elizabeth in neighbouring towns (Refer to figure 1 below). The possible reason why most of the respondents were from Port Elizabeth is because the TLBNR is a small event and therefore mostly attracts participants from around the Port Elizabeth area. Another reason could be because the TLBNR occured on a week day, in the evening which makes it inconvenient for people who reside outside PE to travel. This meant that the participants either had to travel to their home towns after the event, or sleep over in Port Elizabeth.

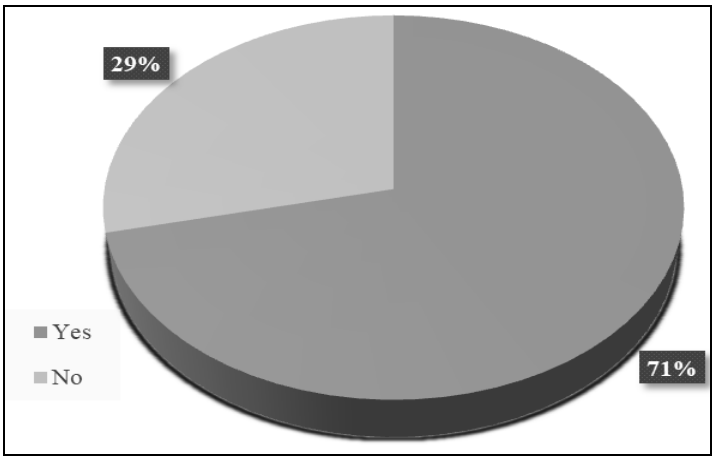

Figure 1. Origin of spectators

The findings of this study with regard to gender revealed that the sample drawn consisted of 56.3 percent being males and 43.7 percent being females.

In similar studies on sports events, such as that of Nyikana (2013), the majority of the respondents were mostly males. Table 1 below indicates that the majority $(83.2 \%)$ of the respondents were between the ages of 18 and 40 years.

In similar studies on sports events, such as Mboyiya (2017) and Nyikana (2013), the largest proportion of respondents were mostly between the ages of 18 to 35 . In addition, Achu et al. (2015) revealed that the sports event spectators were generally young, that is, 18 to 34 years old.

Table 2. Cross tabulating age and environmental awareness

Table 1. Age group of the respondents

\begin{tabular}{|c|c|c|c|c|}
\hline Age & $\begin{array}{c}\mathbf{N} \\
\text { (Count) }\end{array}$ & $\begin{array}{c}\text { Cumulative } \\
\text { count }\end{array}$ & Percent & $\begin{array}{c}\text { Cumulative } \\
\text { percentage }\end{array}$ \\
\hline $18-30$ & 54 & 54 & 45.4 & 45.4 \\
\hline $31-40$ & 45 & 99 & 37.8 & 83.2 \\
\hline $41-50$ & 10 & 109 & 8.4 & 91.6 \\
\hline $51-60$ & 7 & 116 & 5.9 & 97.5 \\
\hline $61+$ & 3 & 119 & 2.5 & 100 \\
\hline Total & $\mathbf{1 1 9}$ & & $\mathbf{1 0 0}$ & \\
\hline
\end{tabular}

\begin{tabular}{|l|c|c|c|c|c|c|}
\hline \multirow{2}{*}{$\begin{array}{c}\text { Environmental } \\
\text { awareness }\end{array}$} & $\mathbf{1 8 - 3 0}$ & $\mathbf{3 1 - 4 0}$ & $\mathbf{4 1 - 5 0}$ & $\mathbf{5 1 - 6 0}$ & $\mathbf{6 1 +}$ & Row total \\
\hline No & 0 & 2 & 3 & 3 & 1 & 9 \\
\hline Total \% & $0.0 \%$ & $1.7 \%$ & $2.5 \%$ & $2.5 \%$ & $0.8 \%$ & $7.5 \%$ \\
\hline To a little extent & 14 & 5 & 2 & 1 & 0 & 22 \\
\hline Total \% & $11.8 \%$ & $4.2 \%$ & $1.7 \%$ & $0.8 \%$ & $0.0 \%$ & $18.5 \%$ \\
\hline To a large extent & 40 & 38 & 5 & 3 & 2 & 88 \\
\hline Total \% & $33.6 \%$ & $31.9 \%$ & $4.2 \%$ & $2.5 \%$ & $1.7 \%$ & $73.9 \%$ \\
\hline Total & 54 & 45 & 10 & 7 & 3 & 119 \\
\hline Total \% & $45.4 \%$ & $37.8 \%$ & $8.4 \%$ & $5.9 \%$ & $2.5 \%$ & $100 \%$ \\
\hline
\end{tabular}

\section{Age and environmental awareness}

With reference to Table 2 below, the younger respondents, namely those between the ages of 18 and 40 years, were too a large extent environmentally aware $(65.5 \%)$, compared to the respondents who were 41 and older $(8.4 \%)$. In general, the majority (73.9\%) of the respondents were to a large extent environmentally aware. This bodes well for the city of Port Elizabeth and sporting events, as it infers that spectators to sporting events have a high environmental awareness. Therefore, sport event planners and administrators need to capitalize on this, and ensure that sport events consider the environmental awareness of their spectators, so as to ensure that the event meets the expectation of the spectators.

\section{Level of education of the respondents}

Table 3 below shows that about $43.7 \%$ of respondents had university education. This was followed by those with high school education (29.4\%) and those with a college education (24.4\%). Therefore, the majority (68.1\%) of the spectators had a post-school education. The reason for this was that the TLBNR is mostly supported by companies (corporates), with most of the spectators possibly being employed by those participating companies. In support of the above, Achu et al. (2015) revealed that sport events are generally attended by well educated people, with the majority having attained a diploma or postgraduate degree.

Table 3. Highest level of education of the respondents

\begin{tabular}{|c|c|c|c|c|}
\hline $\begin{array}{c}\text { Education } \\
\text { level }\end{array}$ & $\begin{array}{c}\mathbf{N} \\
\text { (Count) }\end{array}$ & $\begin{array}{c}\text { Cumulative } \\
\text { count }\end{array}$ & Percent & $\begin{array}{c}\text { Cumulative } \\
\text { percentage }\end{array}$ \\
\hline $\begin{array}{c}\text { Primary } \\
\text { school }\end{array}$ & 3 & 3 & 2.5 & 2.5 \\
\hline $\begin{array}{c}\text { High } \\
\text { school }\end{array}$ & 35 & 38 & 29.4 & 31.9 \\
\hline College & 29 & 67 & 24.4 & 56.3 \\
\hline University & 52 & 119 & 43.7 & 100 \\
\hline Total & $\mathbf{1 1 9}$ & & $\mathbf{1 0 0}$ & \\
\hline
\end{tabular}

Table 4. Cross-tabulation of level of education and environmental awarenes

\begin{tabular}{|c|c|c|c|c|c|}
\hline \multirow{2}{*}{$\begin{array}{l}\text { Environmental } \\
\text { awareness }\end{array}$} & \multicolumn{5}{|c|}{ Level of education } \\
\hline & Primary school & High school & College & University & Row total \\
\hline No & 2 & 4 & 0 & 0 & 6 \\
\hline Total $\%$ & $1.7 \%$ & $3.4 \%$ & $0.0 \%$ & $0.0 \%$ & $5.1 \%$ \\
\hline To a little extent & 1 & 11 & 10 & 15 & 37 \\
\hline Total $\%$ & $0.8 \%$ & $9.2 \%$ & $8.4 \%$ & $12.6 \%$ & $31 \%$ \\
\hline To a large extent & 0 & 20 & 19 & 37 & 76 \\
\hline Total \% & $0.0 \%$ & $16.8 \%$ & $16 \%$ & $31.1 \%$ & $63.9 \%$ \\
\hline Total & 3 & 35 & 29 & 52 & 119 \\
\hline Total $\%$ & $2.5 \%$ & $29.4 \%$ & $24.4 \%$ & $43.7 \%$ & $100.0 \%$ \\
\hline
\end{tabular}




\section{Level of education and environmental awareness}

The majority of respondents (63.9\%) were to a large extent environmentally aware, while $36.1 \%$ had little, or no environmental awareness. At the same time, those respondents with a university qualification, were to a large extent environmentally aware. From this, it can be inferred that as the level of education increased, the more environmentally aware respondents would become.

\section{Environmental intepretation}

In this section the findings regarding how the spectators interpreted concepts related to the environment. A 5-point Likert scale was used to measure the responses of the spectators, based on the the following categories: strongly agree (SA), agree $(A)$, neutral $(\mathrm{N})$, disagree (D) or strongly disagree (SD). For the purpose of this analyses and reporting, the percentages for categories strongly agree and agree have been combined, as well as the percentages for the categories of disagree and strongly disagree, so as to present a clearer picture.

Table 5. Environmental interpretation

\begin{tabular}{|c|c|c|c|c|c|c|c|}
\hline Statements & SA & $\mathbf{A}$ & $\mathbf{N}$ & $\mathbf{D}$ & SD & $\begin{array}{l}\text { Std } \\
\text { Dev }\end{array}$ & $\begin{array}{l}\text { Cronb } \\
\text { Alpha }\end{array}$ \\
\hline An environment involves the natural and built surroundings at a destination (e.g. open space) & 35.3 & 37.8 & 12.6 & 2.5 & 11.8 & 1.3 & \multirow{9}{*}{0.76} \\
\hline I am satisfied with the current environmental state of this area & 29.4 & 32.8 & 20.2 & 10.9 & 6.7 & 1.2 & \\
\hline The conservation and preservation practices are important actions to protect the environment & 31.9 & 35.3 & 15.1 & 7.6 & 10.1 & 1.3 & \\
\hline Keeping the quality of environment high can contribute in the competitiveness of a destination & 10.9 & 31.9 & 39.5 & 15.2 & 2.5 & 1.0 & \\
\hline The quality of the environment is essential to the tourism industry & 17.7 & 32.8 & 23.5 & 19.3 & 6.7 & 1.2 & \\
\hline The natural environment can be a source of attracting visitors in host communities & 25.2 & 29.4 & 23.5 & 16.0 & 5.9 & 1.2 & \\
\hline The growth in tourism destinations can lead to an increase in pressure on the environment & 19.3 & 31.1 & 21.9 & 16.8 & 10.9 & 1.3 & \\
\hline Events in the environment can threaten the natural resources & 14.3 & 21.0 & 30.3 & 23.5 & 10.9 & 1.2 & \\
\hline Littering and the carbon emissions are examples of adverse environmental problems & 18.5 & 35.3 & 23.5 & 10.1 & 12.6 & 1.3 & \\
\hline
\end{tabular}

The overwhelming majorty (73.1\%) of the respondents (spectators) agreed that the "environment involves the natural and built surroundings at a destination". The spectators were accutely aware what the environment is made up of.

Most (62.2\%) of the spectators indicated that they were "satisfied with the current environemtal state of the area", where the event was held. From this, it can be deduced that the immediate surroundings were the event was held was generally clean and free of any visible pollution, such as, littering. Refer to table 5 . The majority $(67.2 \%)$ of the spectators were of the view that "conservation and preservation practices are important actions to protect the environment". Whilst this statement assumed that spectators knew the difference between conservation and preservation, the spectators were clear that actions, or strategies were needed to protect the environment. Refer to table 5. About $42.8 \%$ were of the view that "keeping the quality of environment high can contribute in the competitiveness of a destination". Therefore, the respondents were reasonably clear that the competitiveness of a destination is linked to the quality of the environment. Refer to table 5.

Just over $50 \%(50.5 \%)$ of the respondents believed that "the quality of the environment is essential to the tourism industry", whilst $54.6 \%$ of the respondents were of the view that "the natural environment can be a source of attracting visitors in host communities". Both these statements suggest that the respondents have some understanding of the role that the environment plays in the tourism industry and specifically in attracting visitors. Refer to table 5.

When examining the two statements "the growth in tourism destinations can lead to an increase in pressure on the environment" and "events in the environment can threaten the natural resources" it is apparent that the respondents are aware that growth and events can impact on the environment and natural resources. Refer to table 5.

It is noted $53.8 \%$ of the spectators were of the view that "littering and carbon emissions are examples of adverse environmental problems". The general outcome of the responses, provides an indication that the respondents (spectators) have clear views of what the environment constitutes and how it is influenced, and the role the environment plays. Refer to table 5.

To measure the reliability or internal consistency of the statements in the previous question (Table 5), Cronbach's alpha was used measure the internal. The Cronbach's alpha is one way of measuring the strength of that consistency and in this instance was $\alpha=0.76$, meaning that the internal reliability was good.

\section{Understanding of environmental impacts of sport events}

This section presents the understanding of respondents (spectators) about the environmental impacts of sport events. The data in Table 6 showed that a large number of the respondents (94.1\%) agreed with the statement that "sports events contributed to an improved local environment, e.g. by providing funds or investments to improve an environment". This view is also supported by Gaffney (2010) as cited in Nyakana (2013). In this regard, it is likely that the sport event contributed to a hype in the immediate vicinity of the event. As a result, the local municipality and stakeholders may have invested some time and money in making sure that the vicinity is maintained and cleaned for the participants, spectators and residents. A large majority $(87.4 \%)$ of the respondents were of the view that "sport events contribute to developing local infrastructure". However, since the event is held in the Nelson Mandela Bay stadium precinct, it is quite likely that the respondents were referring to the funds or investments that were made to enhance the physical and aesthetic appeal of the stadium precinct in 
general. The physical enhancement may also have led to a hightened environmental awareness of the spectators. Refer to table 6. In addition, the majority of the respondents (79\%) also agreed to the statement similar to the one above, indicating that "sports events could provide environmental education programmes to create awareness about the importance of the environment". The environmental education programmes referred to here is likely to be strategies, or promotional campaigns that the local municipality or event organiser adopted during the hosting of the event, for example, reducing littering by using the garbage bins provided. Refer to table 6 . The findings of the study showed that a majority of respondents (89.4\%) agreed with the statement that "sports events attract criticism about the environment, after event". This may be due to insufficient garbage bins, noise pollution, or macro-related issues, such as climate change. In support of this, Nyikana (2013) stated that sports events can attract criticism for their perceived negative impact, such as their major contribution towards climate change, especially if the participants and spectators had travelled long distances to the event. In this case, most of the participants and spectators were from the city nd therefore, locals. Refer to table 6.

Table 6. Understanding of environmental impacts of sport events

\begin{tabular}{|c|c|c|c|c|c|c|c|}
\hline Statements & SA & $\mathbf{A}$ & $\mathbf{N}$ & D & SD & $\begin{array}{l}\text { Std } \\
\text { Dev }\end{array}$ & $\begin{array}{l}\text { Cron } \\
\text { Alpha }\end{array}$ \\
\hline Sport events contribute to an improved local environment (e.g. by providing funds or investment) & 54.6 & 39.5 & 4.2 & 0 & 1.7 & 0.7 & \multirow{9}{*}{0.83} \\
\hline $\begin{array}{l}\text { Sport events provide environmental education programmes to create awareness about } \\
\text { importance of the environment }\end{array}$ & 33.6 & 45.4 & 16.0 & 5.0 & 0 & 0.8 & \\
\hline Sport events contribute to developing local infrastructure & 56.3 & 31.1 & 10.1 & 0.8 & 1.7 & 0.8 & \\
\hline Sport events attract criticisms about the environment after event & 47.4 & 42.3 & 8.5 & 0.9 & 0.9 & 0.7 & \\
\hline Sport events can degrade the environmental quality where the event is held & 55.5 & 35.3 & 7.6 & 0.8 & 0.8 & 0.7 & \\
\hline The behaviour of sport spectators can threaten the host communities' environment & 57.1 & 29.4 & 10.1 & 3.4 & 0 & 0.8 & \\
\hline Spectators of sport events contribute to pollution & 36.1 & 42.0 & 11.8 & 8.4 & 1.7 & 0.9 & \\
\hline Sport events lead to the loss of natural habitat for animals & 23.5 & 34.5 & 20.2 & 15.1 & 6.7 & 1.2 & \\
\hline Spectators can waste natural resources during events (e.g. water and others) & 50.4 & 32.8 & 9.3 & 2.5 & 5.0 & 1.0 & \\
\hline
\end{tabular}

The findings of this study revealed that a large number of respondents agreed $(83.2 \%)$ with the statement that "spectators can waste natural resources during the events" (refer to table 6). This may include excessive water usage which may result in a shortage of water after events. Given the fact that Port Elizabeth is located that in a water scarce region, the hosting of any event, as well as an influx of visitors, will place adidtional strain on an already scarce commodity such as water. If events are not well managed and care is not taken at minimising waste, the local population may end up competing for the use of scarce resources. Therefore, sports events should be used to promote environmental awareness amongst the spectators, as well as the host communities. This can be done through designing strategies to enhance environmental awareness, such as, how to minimise water usage, and reducing litter amongst locals and visitors, including spectators, by adopting sustainable initiatives.

The overall findings concerning spectators views about the environmental impact of sports events showed that most of the respondents had an understanding of these environmental impacts. For the statements in Table 6, the internal consistency was also measured and found to $\alpha=0.83$, meaning that the internal reliability was good.

\section{CONCLUSION}

The study demonstrated that the Town Lodge Business Relay event which has been hosted in Port Elizabeth annually has attracted mostly local participants and spectators. With the focus of the study being on the spectators, it became evident that these spectators' profile is similar to previous studies. However, what was perhaps interesting was that the spectators to this specific event had a reasonably good understanding of the interpretation of the environment, as well as an understanding environmental impacts associated with sport events, specifically the younger and more educated spectators.

The implications for sport event managers, hosts and sponsors is quite significant and the following recommendations are made. Firstly, these stakeholders must know the profile of the spectators to specific events. This will allow the stakeholders to better target their spectators and hopefully attract larger audiences. Secondly, stakeholders need to be aware of how spectators interpretated the environment where the event is being held and realise that spectators are likely to have an awareness of the environmental impacts of sport events and design the vent accordingly. Thirdly, these stakeholders should endeavour to highlight how sport events lessen, or can reduce the environmental impact of sport events. In other words, stakeholders need to communicate how a sport event has mitigated the impact on the environment. Finally, clear strategies need to be devised and communicated to the spectators when the event is being marketed as to how the event has been greened and therefore minimize the carbon footprint. This my be crucial for some spectators to know that efforts have been undertaken to reduce the impact on the environment. These recommendations may contribute to the overall sustainability of a sport event and highlight the fact that spectators may also consider the well being of the environment as key.

\section{Acknowledgements}

The authors acknowledge the assistance of the fieldworkers who assisted with the data collection.

\section{REFERENCES}

Achu, F.N., Nyathi, L.S., Bama, H.K.N., \& Tichaawa, T.M. (2015). Profiles of visitors attending the 2013 Confederation of African Football (CAF) Nations Cup tournament in Port Elizabeth, South Africa. Journal for Physical, health Education, Recreation and Dance, supplement 1 (December), 220-232. 
Achu, F.N. (2019). Pro-environmental behaviour of attendees at a major sport event in Cameroon. GeoJournal of Tourism and Geosites, 27(4), 1307-1320. https://doi.org/10.30892/gtg.27416-435

Altinay, L., Paraskevas, A., \& Jang, S. (2016). Planning research in hospitality and tourism. (2 ${ }^{\text {nd }}$ Ed). Abingdon: Routledge

Barber, I.K.B. (2014). Fundamentals of planning and developing tourism. Harlow, Pearson Education.

Bjelac, Z., \& Radovanovic, M. (2003). Sport events as a form of tourist product, relating to the volume and character of demand. Journal of Sport Tourism, 8(4): 260-269. http://dx.doi.org/10.1080/1477508032000161555

Doole, I., \& Lowe, R. (2001). International marketing strategy. London: Thomson Learning.

Dodouras, S., \& James, P. (2004). Examining the sustainability impacts of mega-sports events: Fuzzy mapping as a new integrated system. In $4^{\text {th }}$ International Postgraduate Research Conference in the Built and Human Environment, $29^{\text {th }}$ March- $2^{\text {nd }}$ April 2004, Salford.

Du Plessis, L. (2010). Tourists' perceptions of tourism impacts on the environment: The case of the South African National Parks. MCom, North-West University.

Florek, M., Breitbarth, T., \& Conejo, F. (2008). Mega events=Mega impacts? Travelling fan's experience and perceptions of the 2006 FIFA World Cup Host Nation. Journal of Sport and Tourism, 13(3), 199-219. https://doi.org/10.1080/14775080802310231

Goeldner, C.R., \& Ritchie, J.R.B. (2012). Tourism: Principles, Practices, Philosophies (12 ${ }^{\text {th }}$ ed.). Canada: John Wiley \& Sons.

Hemmonsbey, J., \& Tichaawa, T.M. (2019). Using non-mega events for destination branding: A stakeholder perspective. GeoJournal of Tourism and Geosites, 24(1), 252-266. https://doi.org/10.30892/gtg.24120-357

Higham, J. (2005). Sport tourism destinations: Issues, opportunities and analysis. Oxford: Elsevier.

Jones, I. (2008). Sport fan and spectators as sport tourists. Journal of Sport and Tourism, 13(3), 161-164. https://doi.org/10. $1080 / 14775080802327102$

Kaiser, M., Ströbel, T., Woratschek, H., \& Durckholz, C. (2019). How well do you know your spectators? A study on spectator segmentation-based preference analysis and willingness to pay for tickets. European Sport Management Quarterly, 19, 2, 178-200. https://doi.org/10.1080/16184742.2018.1499790

Kepulić, A., Perić, M., \& Wuse, N. (2020). Assessing and considering the wide impacts of sport-tourism events: a research agenda review of sustainability and strategies planning elements. Sustainability, 12 (4473) 1-18.

Kiani, M.S., Nazari, L., \& Shahbazpour, L. (2019). Investigating the factors affecting the sustainable management of Sporting Students Worldwide. International Journal of Sport Science and Physical Education, 4(2), 28-32. https://doi.org/10.11648/j.ijsspe.20190402.12

Kruger, E.A. (2015). Spectators' contribution to the environmentl dimension of sustainable events sports tourism. DCom, University of Pretoria.

Leedy, P.D., \& Ormrod, J.E. (2015). Practical Research Planning and Design (11 ${ }^{\text {th }}$ ed.). Pearson Education Limited: Harlow.

Mboyiya, A. (2017). The perceptions of Summerstrand residents about the socio-cultural influences of major sporting events. Nelson Mandela University, Port Elizabeth.

McKay, T., McEwan L., \& Baker, M. (2019). The rise of trail running in South Africa: Possibilities for small-scale sports tourism. GeoJournal of Tourism and Geosites, 26(3), 930-942. https://doi.org/10.30892/gtg.26320-408

Nyakana, S. (2013). Visitor's perception of the 2010 FIFA World Cup: a case study of the host city Nelson Mandela Bay/ Port Elizabeth. Unpublished MTech dissertation. Cape Peninsula University of Technology, Cape Town.

Ramukumba, T. (2016). Profiling visitor characteristics at Tsitsikamma National Park, South Africa. African Journal of Hospitality. Tourism and Leisure, 5 (3), 1-9.

Ritchie, J.R.B., \& Crouch, G.L. (2003). The Competitivve Destination: A Sustainable Tourism Perspective. Wallingford, UK:CABI Publishing.

Smith, A., \& Stewart, B. (2007). The travelling fan: understanding the mechanisms of sport fan consumption in a sport tourism setting. Journal of Sport and Tourism, 12(3-4): 155-181. https://doi.org/10.1080/14775080701736924

Stander, F.W., \& Van Zyl, L.E. (2016). See you at the match: motivation for sport consumption and instrinsic psychological reward of premier football league spectators in South Africa. South African Journal of Industrial Psychology, 42(1). http://dx.doi.org/10.4102/sajip.v42i1.1314

Article history: Received: 01.12.2020 Revised: 16.01.2021 Accepted: 15.03.2021 Available online: 06.04.2021 